\author{
Iryna Kosogina, Igor Astrelin, Natalya Klimenko and Andriy Kontsevoy
}

\title{
REGULARITIES OF LOW-WASTE TECHNOLOGY OF WASTEWATER TREATMENT BY COAGULATION METHOD
}

\author{
National Technical University of Ukraine "KPI" 37, Peremohy Ave., 03056 Kiev, Ukraine \\ i.m.astrelin@xtf.ntu-kpi.kiev.ua; kosogina@gala.net
}

Received: April 01, 2008

\begin{abstract}
Mechanisms of wastewater purification from surface-active substances and of sulphuric acid dissolution of iron-containing sludge formed during the previous process have been established. Kinetic regularities of metal-containing sludge dissolution in sulphuric acid have been investigated. Kinetic equation which adequately presents the experimental data has been proposed; constants of this kinetic equation have been calculated.
\end{abstract}

Keywords: sulphuric-acid dissolution, kinetics, quantumchemical calculation, mechanism.

\section{Introduction}

As imperfections of the existing technology of valuable components of wastewater (WW) treatment sludge regeneration cause accumulation of environmentally hazardous sludge and increase its storage areas, studies within the scope of the mentioned problems are of great importance [1-3].

To increase completeness of WW treatment sludge utilization at simultaneous decrease of the deleterious effect of toxic sludge components on the environment as well as to lower sludge amount in sludge traps and to re-use the initial reagents during the recycling process, kinetics of sulphuric acid dissolution of the textile industry WW treatment sludge is investigated.

The purpose of this article consists in investigating the kinetics of sulphuric acid dissolution of textile industry WW treatment sludge in order to discover and substantiate the process mechanism and technological parameters of sludge acid dissolution. After sludge dissolution a product is formed, which is used during the recycling process thus promoting the decrease in the amount of the formed industry waste products as well as profitability and ecological compatibility of the production.

\section{Experimental}

\subsection{M aterials}

Model of wastewater polluted by the following surface-active substances (SAS): ludigol - $m$-nitrobenzene sodium sulphate, $\mathrm{C}_{6} \mathrm{H}_{4} \mathrm{NO}_{2} \mathrm{SO}_{3} \mathrm{Na}$; methaupon-sodium salt $\mathrm{N}$-methyl taurinate of fatty acid, $\mathrm{RCON}\left(\mathrm{R}^{\prime}\right) \mathrm{CH}_{2} \mathrm{SO}_{3} \mathrm{Na}$; synthanol - mixture polyethylene glycol ethers of synthetic primary alcohols of fraction $\mathrm{C}_{10}-\mathrm{C}_{18}$, $\mathrm{C}_{10} \mathrm{H}_{21} \mathrm{O}\left(\mathrm{C}_{2} \mathrm{H}_{4} \mathrm{O}\right)_{10} \mathrm{H}$, and dye - ruby reactive dye $5 \mathrm{CX}$, $\mathrm{C}_{19} \mathrm{H}_{11} \mathrm{O}_{3} \mathrm{~N}_{6} \mathrm{~S}_{2} \mathrm{Cl}_{2} \mathrm{Na}_{2}$.

\subsection{M ethods}

As a subject of inquiry model solutions of wastewater of Ukrainian textile factories containing totally up to $15 \mathrm{mg} / \mathrm{dm}^{3}$ of SAS (ludigol, methaupon, synthanol) and up to $6 \mathrm{mg} / \mathrm{dm}^{3}$ of ruby reactive dye $5 \mathrm{CX}$ were used. Coagulation treatment of the WW model solutions was carried out by using coagulant $\mathrm{FeSO}_{4} \cdot 7 \mathrm{H}_{2} \mathrm{O}$ at $\mathrm{pH}$ 9-9.5 during 60 minutes.

Since there are no data on kinetics of acid dissolution of iron-containing treatment sludge of the wastewater polluted by dye and SAS in the literature, kinetic regularities of this process were studied.

The process of sulphuric acid dissolution is influenced by such factors as acid concentration, stoichiometric acid excess, temperature regime, dissolution process duration, and finally by the characteristics of the sludge itself. Therefore the description of the kinetic regularities of the process taking into account all the factors is very complicated. Conditions of acid dissolution were selected during the prior experiments in the way to facilitate the achievement of the highest possible iron extraction degree from sludge [4].

Kinetics of sludge dissolution was studied by the integral method. Moist iron-containing sludge was placed into an isothermal reactor with agitator, and the calculated 
amount of sulphuric acid with concentration $12 \%$ was added; sulphuric acid excess to stoichiometry ratio being 1.6. The dissolution time was 1-20 minutes. The content of the regenerated iron in the solution was measured photocolorimetricaly by a standard technique [5] at wavelength $\lambda=440 \mathrm{~nm}$ using $10 \mathrm{~mm}$ thick cuvette.

\section{Results and Discussion}

\subsection{Mechanism of the process of organic components removal from wastewater by coagulation method}

In order to determine the mechanism of sulphuricacid dissolution of iron-containing sludge it is necessary to find a compound capable of forming a macromolecule or a complex with SAS and dyes characteristic of textile industry wastewater.

Qualitative and quantitative composition of sludge depends on the conditions of the wastewater treatment process. During WW coagulation treatment by iron (II) sulphate aquacomplex of iron (II) hydroxide is formed initially, which under dissolved oxygen action depending on hydrolysis conditions can form amorphous aquacomplex of iron (III) hydroxide, crystalline magnetite, and/or lepidocrocite. The presence of crystalline structures of magnetite and lepidocrocite against the background of X-ray amorphous iron (III) hydroxide was confirmed both visually (Fig. 1) and by X-ray analysis (Fig. 2).

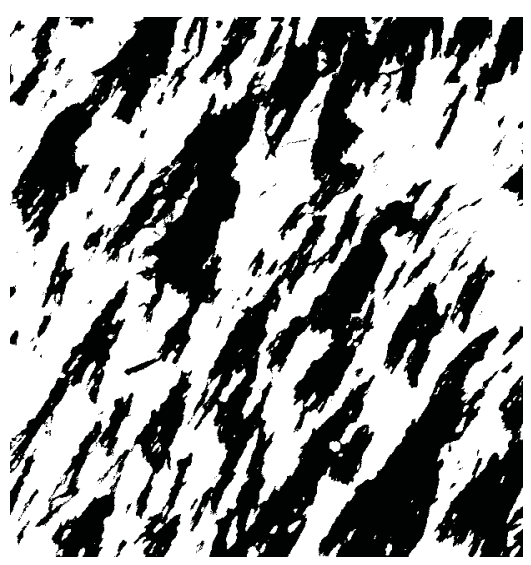

1

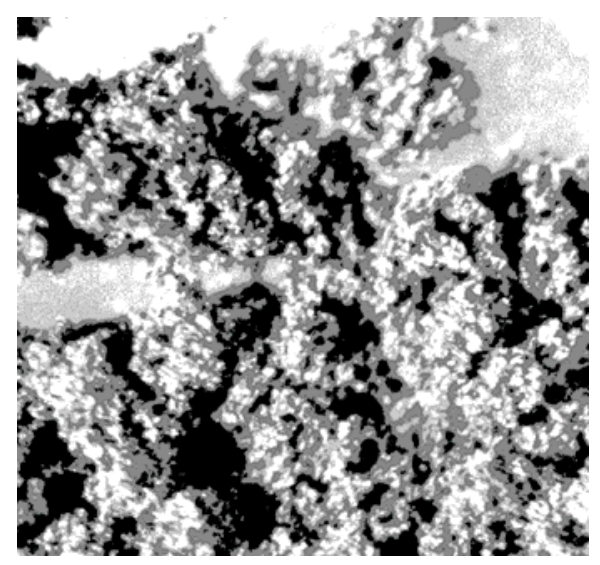

2

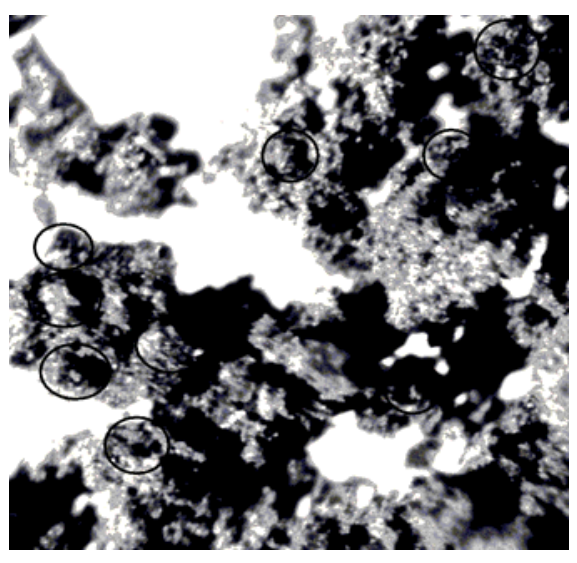

3

Fig. 1. Photomicrographs of fragments of iron containing sludges of different phase composition: magnetite (1), amorphous sludge (2) and lepidocrocite (marked by circles) (3). Magnification Ч16

A basic compound capable of interacting with SAS and dyes is aquacomplex of iron (III) hydroxide. A drawback of magnetite and lepidocrocite formation is their crystalline structure, which makes it impossible to regenerate iron by acid method. However, magnetite is magnetizable, therefore sludge separation and washing processes are facilitated by applying magnetic field.

After iron (III) hydroxide aquacomplex formation, SAS and dyes sorption at hydroxide flakes takes place. As such SAS as ludigol and methaupon are salts of organic acids there is a probability that the sorption process occurs either due to elimination of labile sodium atom and partial substitution of $\mathrm{OH}$-group with acid anion or SAS acting as a ligand owing to unshared electron pairs at nitrogen and oxygen atoms within ludigol and methaupon molecules. Sorption of dye proceeds only due to exchange reactions in external sphere of aquacomplex. Synthanol is kept at iron hydroxide flakes surface only owing to physical adsorption by Van der Waals' forces. After formation and precipitation of iron-organic complex macromolecules, sludge separation from supernatant by decantation was carried out. Sulphuric-acid dissolution of iron-organic sludge occurs with formation of iron (III) sulphate and organic acids of corresponding SAS.

It is possible to represent the mechanism of WW purification from SAS and dye by iron-containing coagulant as follows:

1 stage - formation of aquacomplex of iron (II):

$\left[\mathrm{Fe}\left(\mathrm{H}_{2} \mathrm{O}\right)_{6}\right] \mathrm{SO}_{4}+2 \mathrm{NaOH}=\left[\mathrm{Fe}\left(\mathrm{H}_{2} \mathrm{O}\right)_{6}\right](\mathrm{OH})_{2}+\mathrm{Na}_{2} \mathrm{SO}_{4}$

2 stage - formation of hydrolysates of iron (II):

a) $4\left[\mathrm{Fe}\left(\mathrm{H}_{2} \mathrm{O}\right)_{6}\right](\mathrm{OH})_{2}+\mathrm{O}_{2}+2 \mathrm{H}_{2} \mathrm{O}=4\left[\mathrm{Fe}\left(\mathrm{H}_{2} \mathrm{O}\right)_{6}\right](\mathrm{OH})_{3}$;

b) $\left.3 \mathrm{Fe}\left(\mathrm{H}_{2} \mathrm{O}\right)_{6}\right](\mathrm{OH})_{2}+0.5 \mathrm{O}_{2}=\mathrm{FeO} \cdot \mathrm{Fe}_{2} \mathrm{O}_{3}+21 \mathrm{H}_{2} \mathrm{O}$; c) $4\left[\mathrm{Fe}\left(\mathrm{H}_{2} \mathrm{O}\right)_{6}\right](\mathrm{OH})_{2}+\mathrm{O}_{2}=4 \mathrm{FeO}(\mathrm{OH})+26 \mathrm{H}_{2} \mathrm{O}$; 

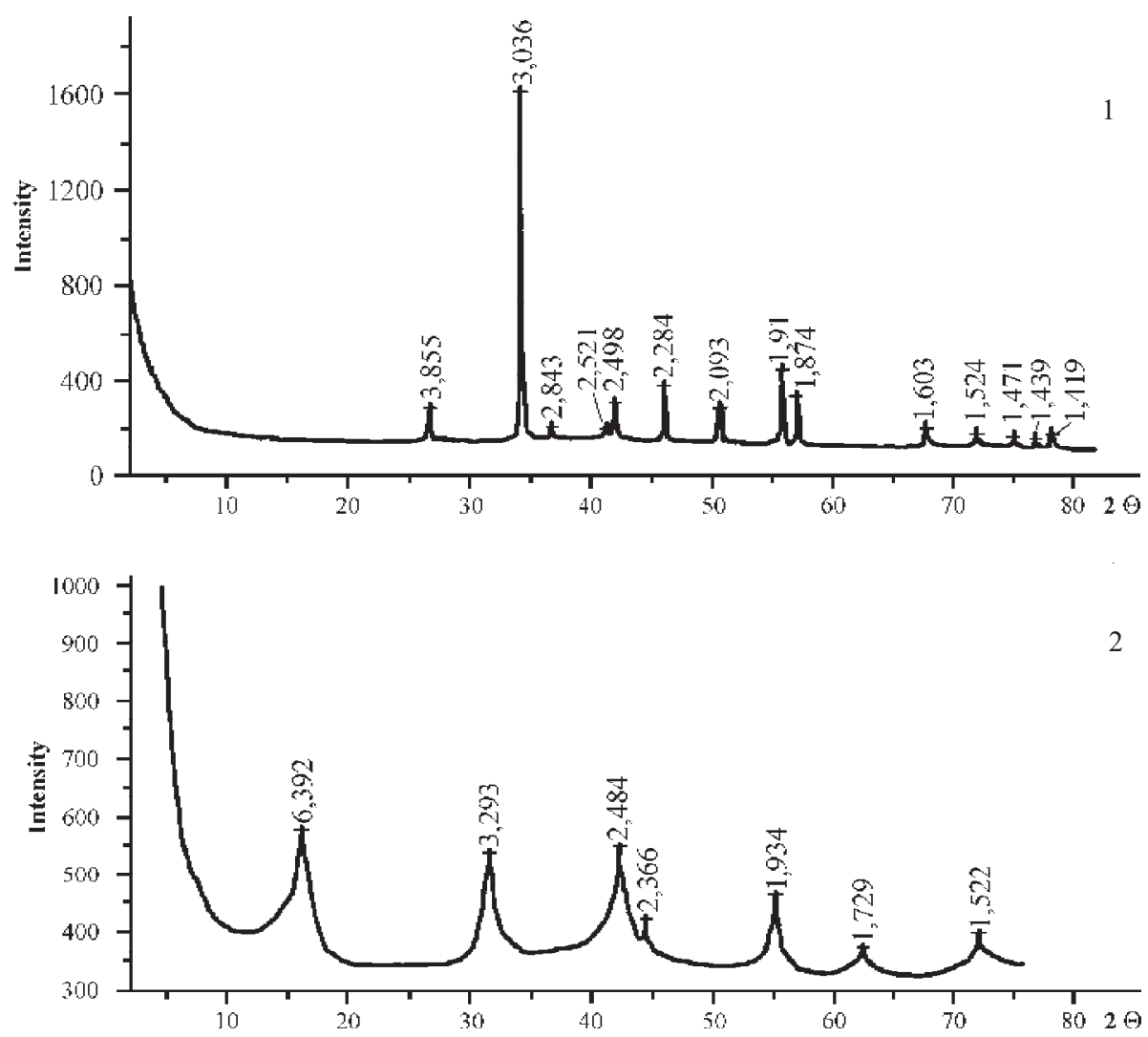

Fig. 2. Roentgenograms of iron containing sludges: magnetite (1) and lepidocrocite (2)

3 stage - interaction of iron (III) hydroxide with SAS and dye in WW:

with ludigol

$\left.\mathrm{a}^{1}\right)\left[\mathrm{Fe}\left(\mathrm{H}_{2} \mathrm{O}\right)_{6}\right](\mathrm{OH})_{3}+\mathrm{C}_{6} \mathrm{H}_{4} \mathrm{NO}_{2} \mathrm{SO}_{3} \mathrm{Na}==\left[\mathrm{Fe}\left(\mathrm{H}_{2} \mathrm{O}\right)_{6}\right](\mathrm{OH})_{2}\left(\mathrm{C}_{6} \mathrm{H}_{4} \mathrm{NO}_{2} \mathrm{SO}_{3}\right)+\mathrm{NaOH}$;

$\left.\mathrm{a}^{2}\right)\left[\mathrm{Fe}\left(\mathrm{H}_{2} \mathrm{O}\right)_{6}\right](\mathrm{OH})_{3}+6 \mathrm{C}_{6} \mathrm{H}_{4} \ddot{\mathrm{N}} \mathrm{O}_{2} \mathrm{SO}_{3} \mathrm{Na}=\mathrm{Na}_{3}\left[\mathrm{Fe}\left(\mathrm{C}_{6} \mathrm{H}_{4} \ddot{\mathrm{N}} \mathrm{O}_{2} \mathrm{SO}_{3}\right)_{6}\right]+3 \mathrm{NaOH}+6 \mathrm{H}_{2} \mathrm{O}$;

or in structural view:

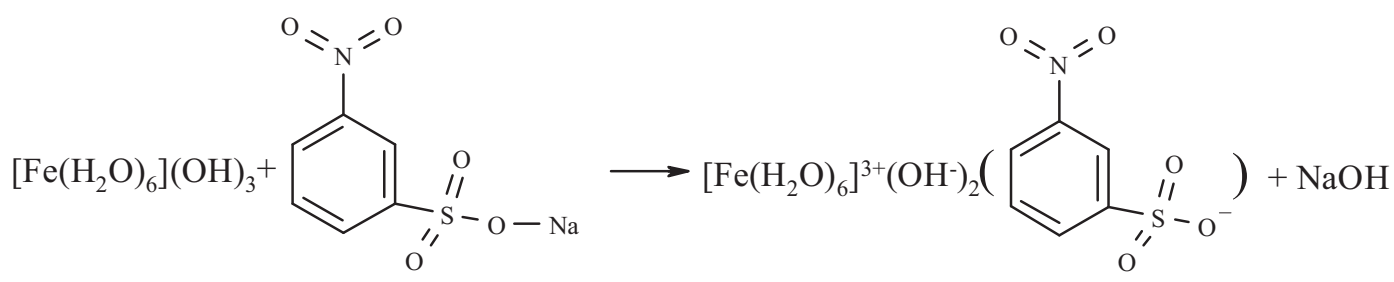

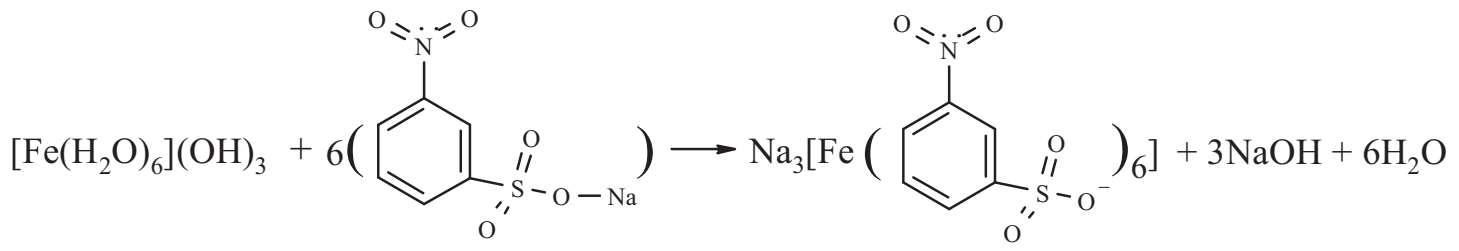

with methaupon

$\left.b^{1}\right)\left[\mathrm{Fe}\left(\mathrm{H}_{2} \mathrm{O}\right)_{6}\right](\mathrm{OH})_{3}+\mathrm{C}_{21} \mathrm{H}_{40} \mathrm{ONSO}_{3} \mathrm{Na}=\left[\mathrm{Fe}\left(\mathrm{H}_{2} \mathrm{O}\right)_{6}\right](\mathrm{OH})_{2}\left(\mathrm{C}_{21} \mathrm{H}_{40} \mathrm{ONSO}_{3}\right)+\mathrm{NaOH} ;$

$\left.b^{2}\right)\left[\mathrm{Fe}\left(\mathrm{H}_{2} \mathrm{O}\right)_{6}\right](\mathrm{OH})_{3}+6 \mathrm{C}_{21} \mathrm{H}_{40} \mathrm{O} N \mathrm{NO}_{3} \mathrm{Na}=\mathrm{Na}_{3}\left[\mathrm{Fe}\left(\mathrm{C}_{21} \mathrm{H}_{40} \mathrm{ONSO}\right)_{6}\right]+3 \mathrm{NaOH}+6 \mathrm{H}_{2} \mathrm{O}$;

$\left.b^{3}\right)\left[\mathrm{Fe}\left(\mathrm{H}_{2} \mathrm{O}\right)_{6}\right](\mathrm{OH})_{3}+3 \mathrm{C}_{21} \mathrm{H}_{40} \ddot{\mathrm{O}} \ddot{\mathrm{N}} \mathrm{SO}_{3} \mathrm{Na}=\mathrm{Fe}\left(\mathrm{C}_{21} \mathrm{H}_{40} \mathrm{O} \ddot{\mathrm{N}} \mathrm{SO}_{3}\right)_{3}+3 \mathrm{NaOH}$; 
with ruby reactive dye $5 \mathrm{CX}$

c) $\left[\mathrm{Fe}\left(\mathrm{H}_{2} \mathrm{O}\right)_{6}\right](\mathrm{OH})_{3}+\mathrm{C}_{19} \mathrm{H}_{9} \mathrm{~N}_{6} \mathrm{Cl}(\mathrm{OH})\left(\mathrm{SO}_{3} \mathrm{Na}\right)_{2}=\left[\mathrm{Fe}\left(\mathrm{H}_{2} \mathrm{O}\right)_{6}\right]^{3+}\left(\mathrm{C}_{19} \mathrm{H}_{9} \mathrm{~N}_{6} \mathrm{Cl}_{2}\left(\mathrm{O}^{-}\right)\left(\mathrm{SO}_{3}^{-}\right)_{2}+\mathrm{H}_{2} \mathrm{O}+2 \mathrm{NaOH}\right.$; or in structural view:

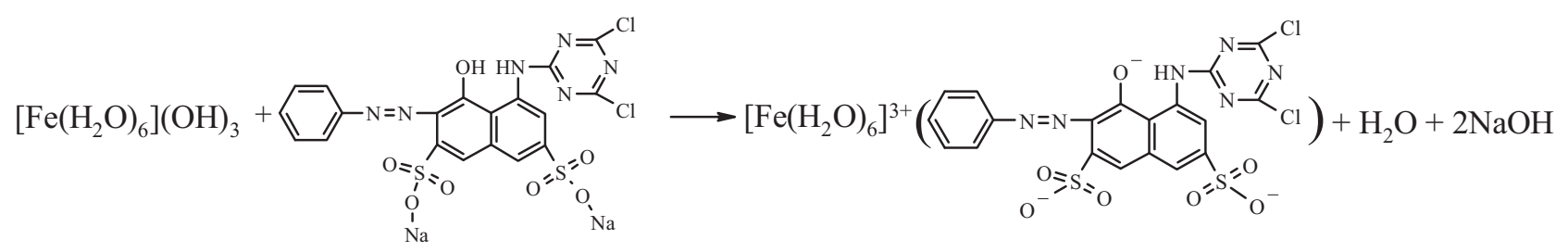

4 stage - sludge dissolution in acid:

$$
\begin{aligned}
& 2\left[\mathrm{Fe}\left(\mathrm{H}_{2} \mathrm{O}\right)_{6}\right](\mathrm{OH})_{2}\left(\mathrm{C}_{6} \mathrm{H}_{4} \mathrm{NO}_{2} \mathrm{SO}_{3}\right)+3 \mathrm{H}_{2} \mathrm{SO}_{4}=\left[\mathrm{Fe}\left(\mathrm{H}_{2} \mathrm{O}\right)_{6}\right]_{2}\left(\mathrm{SO}_{4}\right)_{3}+2 \mathrm{C}_{6} \mathrm{H}_{4} \mathrm{NO}_{2} \mathrm{SO}_{3} \mathrm{H}+4 \mathrm{H}_{2} \mathrm{O} \\
& 2 \mathrm{Na}_{3}\left[\mathrm{Fe}\left(\mathrm{C}_{6} \mathrm{H}_{4} \ddot{\mathrm{N}} \mathrm{O}_{2} \mathrm{SO}_{3}\right)_{6}\right]+3 \mathrm{H}_{2} \mathrm{SO}_{4}+12 \mathrm{H}_{2} \mathrm{O}=\left[\mathrm{Fe}\left(\mathrm{H}_{2} \mathrm{O}\right)_{6}\right]_{2}\left(\mathrm{SO}_{4}\right)_{3}+6 \mathrm{C}_{6} \mathrm{H}_{4} \ddot{\mathrm{N}} \mathrm{O}_{2} \mathrm{SO}_{3} \mathrm{Na}+6 \mathrm{C}_{6} \mathrm{H}_{4} \ddot{\mathrm{N}} \mathrm{O}_{2} \mathrm{SO}_{3} \mathrm{H} \text {; } \\
& 2\left[\mathrm{Fe}\left(\mathrm{H}_{2} \mathrm{O}\right)_{6}\right](\mathrm{OH})_{2}\left(\mathrm{C}_{21} \mathrm{H}_{40} \mathrm{ONSO}_{3}\right)+3 \mathrm{H}_{2} \mathrm{SO}_{4}=\left[\mathrm{Fe}\left(\mathrm{H}_{2} \mathrm{O}\right)_{6}\right]_{2}\left(\mathrm{SO}_{4}\right)_{3}+2 \mathrm{C}_{21} \mathrm{H}_{40} \mathrm{ONSO}_{3} \mathrm{H}+4 \mathrm{H}_{2} \mathrm{O} \text {; } \\
& \left.2 \mathrm{Na}_{3}\left[\mathrm{Fe}\left(\mathrm{C}_{21} \mathrm{H}_{40} \ddot{\mathrm{N}} \ddot{\mathrm{SO}}\right)_{3}\right)\right]+3 \mathrm{H}_{2} \mathrm{SO}_{4}+12 \mathrm{H}_{2} \mathrm{O}= \\
& =\left[\mathrm{Fe}\left(\mathrm{H}_{2} \mathrm{O}\right)_{6}\right]_{2}\left(\mathrm{SO}_{4}\right)_{3}+6 \mathrm{C}_{21} \mathrm{H}_{40} \ddot{\mathrm{OSO}} \mathrm{Sa}_{3}+6 \mathrm{C}_{21} \mathrm{H}_{40} \mathrm{O} \ddot{\mathrm{N}} \mathrm{SO}_{3} \mathrm{H} \\
& 2 \mathrm{Fe}\left(\mathrm{C}_{21} \mathrm{H}_{40} \ddot{\mathrm{O}} \ddot{\mathrm{N}} \mathrm{SO}_{3}\right)_{3}+3 \mathrm{H}_{2} \mathrm{SO}_{4}+12 \mathrm{H}_{2} \mathrm{O}=\left[\mathrm{Fe}\left(\mathrm{H}_{2} \mathrm{O}\right)_{6}\right]_{2}\left(\mathrm{SO}_{4}\right)_{3}+3 \mathrm{C}_{21} \mathrm{H}_{40} \mathrm{O} \ddot{\mathrm{N}} \mathrm{SO}_{3} \mathrm{H} ; \\
& 2\left[\mathrm{Fe}\left(\mathrm{H}_{2} \mathrm{O}\right)_{6}\right]^{3+}\left(\mathrm{C}_{19} \mathrm{H}_{9} \mathrm{~N}_{6} \mathrm{Cl}_{2}\left(\mathrm{O}^{-}\right)\left(\mathrm{SO}_{3}^{-}\right)_{2}+3 \mathrm{H}_{2} \mathrm{SO}_{4}=\left[\mathrm{Fe}\left(\mathrm{H}_{2} \mathrm{O}\right)_{6}\right]_{2}\left(\mathrm{SO}_{4}\right)_{3}+2 \mathrm{C}_{19} \mathrm{H}_{9} \mathrm{~N}_{6} \mathrm{Cl}_{2}(\mathrm{OH})\left(\mathrm{SO}_{3} \mathrm{H}\right)_{2}\right. \text {; }
\end{aligned}
$$

5 stage - recycling of regenerated coagulant:

$$
\left[\mathrm{Fe}\left(\mathrm{H}_{2} \mathrm{O}\right)_{6}\right]_{2}\left(\mathrm{SO}_{4}\right)_{3}+6 \mathrm{NaOH}=2\left[\mathrm{Fe}\left(\mathrm{H}_{2} \mathrm{O}\right)_{6}\right](\mathrm{OH})_{3}+3 \mathrm{Na}_{2} \mathrm{SO}_{4} \text {. }
$$

\section{2. $Q$ uantum-chemical calculation of thermodynamic characteristics of the initial substances}

The literary sources provide no information concerning the mechanism of SAS and dye interaction with coagulants, therefore quantum-chemical calculation of thermodynamic characteristics of the initial substances was carried out to determine the thermodynamic possibility of this process running according to the presented mechanism (Table, Fig. 3). Quantum-chemical calculation of structure and thermodynamic properties of SAS is conducted using Hypercube Hyperchem Professional v7.01 (trial) program.

\subsection{Kinetics of sulphuric-acid dissolution of iron-containing sludge}

Characteristic integral and differential curves of acid sludge dissolution are presented in Fig. 4. In order to determine iron-containing sludge dissolution by sulphuric acid rate, approximation of the dependence of sludge dissolution process duration effect on iron extraction rate into solution $X=f(\tau)$ by a quadric equation is carried out.

For mathematical description of the process, a part of the experimental data was not taken into account because, after 15 minutes of sulphuric acid contact with sludge the process decelerates and then almost reaches equilibrium condition (marked on the figure by the dotted line).

For each of three curves, polynomial and reliability $R^{2}$ approximations are as follows:

for curve 1 :

$X=-0.0009 \tau^{2}+0.0310 \tau+0.4666 \quad R^{2}=0.9971$

for curve 2:

$X=-0.0009 \tau^{2}+0.0307 \tau+0.5208 \quad R^{2}=0.9997$

for curve 3:

$X=-0.0005 \tau^{2}+0.0223 \tau+0.6279 \quad R^{2}=0.9993$

By derivation of the received polynomials at the fixed time $(\tau)$ values, experimental values of sludge dissolution by acid rate $W_{\text {ekc }}$ were calculated and expressed through the change of rate of iron extraction from sludge $(X)$ :

$$
W_{e k c}=\frac{d X}{d \tau} .
$$

Thermodynamic characteristics of the basic wastewater contaminants

\begin{tabular}{|l|c|c|c|}
\hline \multicolumn{1}{|c|}{ Pollutant } & Total energy, kJ/mol & $\begin{array}{c}\text { Binding energy, } \\
\mathrm{kJ} / \mathrm{mol}\end{array}$ & $\begin{array}{c}\text { Heat of formation, } \\
\mathrm{kJ} / \mathrm{mol}\end{array}$ \\
\hline Ludigol & 3870.0 & 198.8 & 527.9 \\
\hline Methaupon & 7040.8 & 697.8 & 1458.1 \\
\hline Synthanol & 7484.1 & 401.2 & 3775.9 \\
\hline Ruby reactive dye 5 CX & 10113.3 & 642.7 & 1034.0 \\
\hline
\end{tabular}



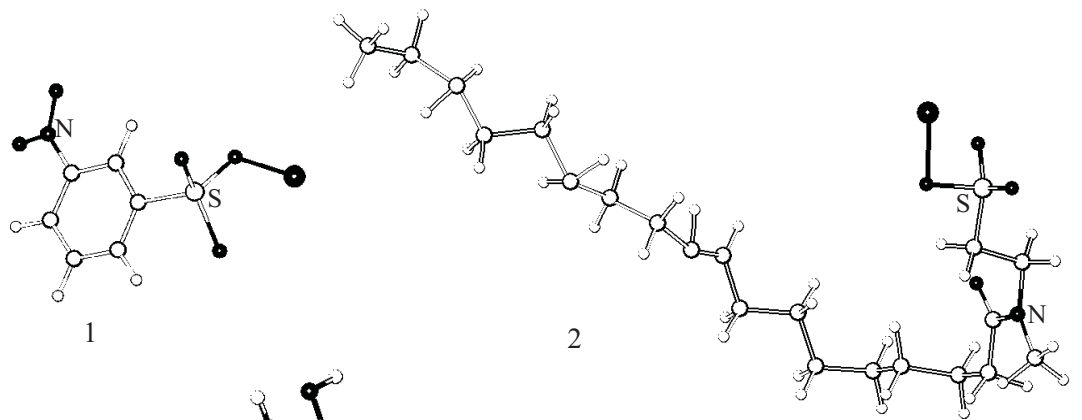

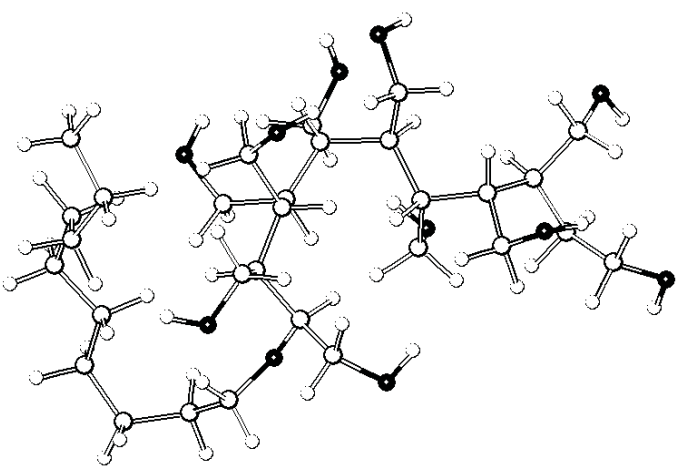

3

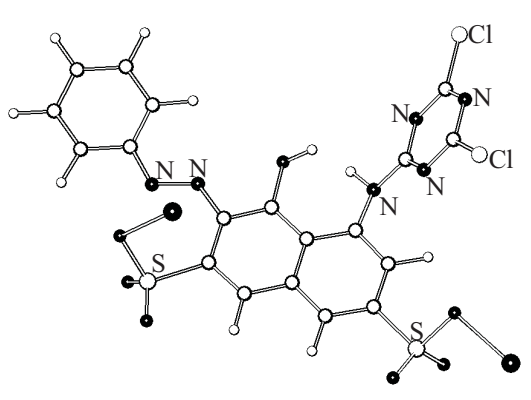

4

Common legend:

O-C; ○- $\mathrm{H} ; \bullet-\mathrm{O} ; \bullet-\mathrm{Na}$.

Fig. 3. Structures of the basic wastewater contaminants: SAS ludigol (1), methaupon (2), synthanol (3) and ruby reactive dye 5 CX (4)

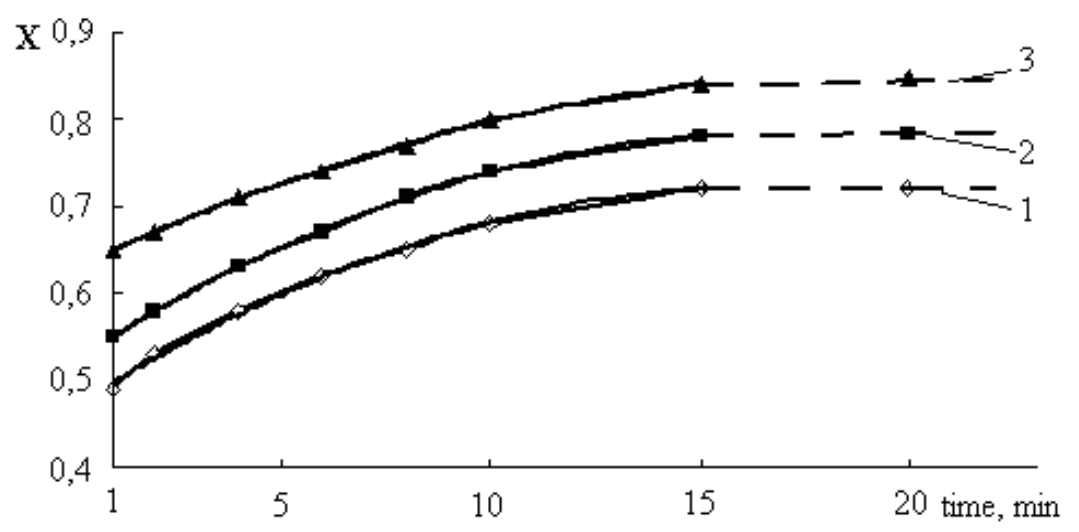

Fig. 4. Isothermal kinetics of sludge acid decomposition at temperatures: $293 \mathrm{~K}$ (1), $298 \mathrm{~K}(2)$ and $303 \mathrm{~K}(3)$

$\mathrm{H}_{2} \mathrm{SO}_{4}$ concentration and excess (from stoichiometry) $12 \%$ and 1.6, respectively

Calculated process rate $W_{p}$ can be represented as follows:

$$
W_{p}=k \cdot(1-X)^{n},
$$

where $k$ is kinetic constant of the process, $X$ - rate of iron from sludge extraction, $n$ - order of reaction.

$$
k=k_{0} e^{\frac{-E}{R T}}
$$

where $k_{0}$ - preexponential factor, $E$ - activation energy, $\mathrm{J} /(\mathrm{mol} \cdot \mathrm{K})$.
Then the equation for description of acid sludge dissolution kinetics should have the following view:

$$
W_{p}=k_{0} e^{\frac{-E}{R T}} \cdot(1-X)^{n}
$$

After the transformations equation (2) takes the following form:

$$
W_{p}=\ln k_{0}-\frac{E}{R} \cdot \frac{1}{T}+n \ln (1-X)
$$

Calculation of the unknowns of equation (3) was carried out in Microsoft Office Excel using function "LINEAR". 
Kinetic parameters of equation (2) are as follows: $k_{0}=12355 ; E=30300 \mathrm{~J} /(\mathrm{mol} \cdot \mathrm{K}) ; n=0,96$. Mean relative difference between the experimentally measured and calculated rates does not exceed $\pm 12.5 \%$. Order $n$ and activation energy value $E$ indicate the probability of the process of acid dissolution of iron-containing sludge occurrence in internal diffusion range.

\section{Conclusions}

The mechanism of wastewater purification from SAS and dyes by iron-containing coagulant has been established. The main compound capable of reacting with SAS and dye is aquacomplex of iron (III) hydroxide. The process of sulphuric-acid dissolution of iron-containing sludge takes place in external diffusion range, i.e. dissolution rate depends on the rate of sulphuric acid diffusion. As a result of dissolution, iron (III) sulphate is formed, which is further used as a coagulant for typical WW treatment. However, the regenerated coagulant solution is polluted with the residues of SAS and their derivatives, therefore, before using the obtained iron (III) sulphate solution, it is necessary to treat the coagulant by catalytic system $\mathrm{H}_{2} \mathrm{O}_{2}-\mathrm{Fe}^{2+}\left(\mathrm{Fe}^{3+}\right)$.

\section{Acknowledgements}

This work has been done under the financial support of Ministry of Education and Science of Ukraine (grant
No. 0107U002381) and Department of Science and Innovation of NTUU "KPI" (grant No. 4/9 for young researchers).

\section{References}

[1] Adamenko O., Cheljadin L., Cheljadin V. and Skrobach M.: Ekotechnologii i Resursozberezhenie, 2007, 6, 68.

[2] Sidko R., Kerzhener B. and Shevchenko M.: Khimia i Technologia vody, 1986, 8, 50.

[3] Dontsova M., Romodanova V. and Kulskiy L.: Stroitelstvo i Arhitektura, 1978, 2, 117.

[4] Kosogina I., Astrelin I. and Klimenko N.: Ekotechnologii i Resursozberezhenie, 2007, 6, 53.

[5] Lurje J.: Analiticheskaya khimiya promyshlennyh stochnyh vod. Khimiya, Moskva 1984.

\section{ЗАКОНОМІРНОСТІ МАЛОВІДХОДНОЇ ТЕХНОЛОГІЇ ОЧИЩЕННЯ СТІЧНИХ ВОД КОАГУЛЯЦІЙНИМ МЕТОДОМ}

Анотація. Встановлено механізм процесу очищення стічних вод від поверхнево активних речовин та сульфатнокислотного розчинення, утвореного в результаті очищення ферумвмісного осаду. Досліджено кінетичні закономірності розчинення металовмісного осаду сульфатною кислотою. Запропоновано кінетичне рівняння, яке адекватно описує експериментальні дані; розраховані константи кінетичного рівняння.

Ключові слова: сульфатно-кислотне розчинення, кінетика, квантово-хімічний розрахунок, механізм. 